\title{
STUDIES ON THE HELMINTH FAUNA OF JAPAN PART 55. FOUR NEW GENERA OF ACANTHOCEPHALA FROM FISHES
}

\author{
$\operatorname{AUTHOR}(\mathrm{S}):$ \\ Yamaguti, Satyu
}

\section{CITATION:}

Yamaguti, Satyu. STUDIES ON THE HELMINTH FAUNA OF JAPAN PART 55. FOUR NEW GENERA OF ACANTHOCEPHALA FROM FISHES. PUBLICATIONS OF THE SETO MARINE BIOLOGICAL LABORATORY 1959, 7(3): 319-326

ISSUE DATE:

1959-12-20

URL:

http://hdl.handle.net/2433/174636

RIGHT: 


\title{
STUDIES ON THE HELMINTH FAUNA OF JAPAN \\ PART 55. FOUR NEW GENERA OF ACANTHOCEPHALA FROM FISHES
}

\author{
SATYU YAMAGUTI \\ Department of Parasitology, Okayama University \\ Medical School, Okayama
}

With Plate XXVI

\section{CONTENTS}

Echinorhynchidae CoвBoLd, 1879

Page

1. Metacanthocephalus pleuronichthydis n. g., n. sp. .........................319

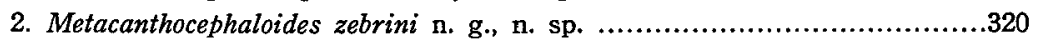

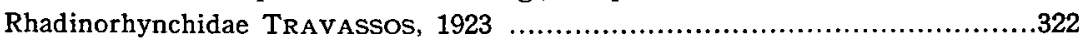

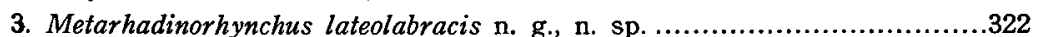

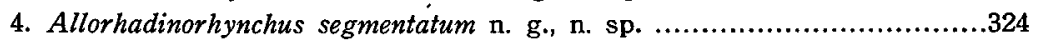

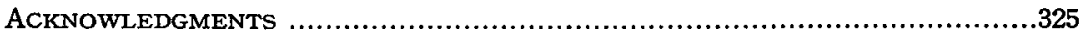

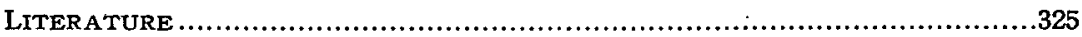

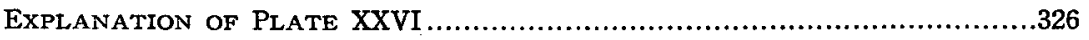

ECHINORHYNCHIDAE COBBOLD, 1879

1. Metacanthocephalus pleuronichthydis n. g., n. sp.

(Pl. XXVI, Figs. 1-3)

Habitat: Small intestine of Pleuronichthys cornutus (Temm. et Schleg.)

Material: 15 mature males and 23 mature or gravid females.

Locality and date: Inland Sea; September 9, 1957.

Male. Proboscis subcylindrical, broadly rounded in front, $0.43-0.5 \times 0.27-0.4 \mathrm{~mm}$, with 21-26 longitudinal rows of 7-10 hooks each; largest subapical hooks $62-78 \mu$ long; smallest basal hooks $41-55 \mu$ long. Neck very short. Proboscis sheath subcylindrical to claviform, double-walled, $0.7-1.0 \times 0.28-0.4 \mathrm{~mm}$, with ganglion at its anterior end. Lemnisci fattened, usually longer than proboscis sheath, up to $1.0-1.2 \mathrm{~mm}$ long when extended. Trunk subcylindrical, 5.0-6.5 $\times 0.7-1.0 \mathrm{~mm}$, with numerous, small, partly branched, hypodermal nuclei. Testes rounded, directly tandem, in midregion of trunk or more or less posterior to it; anterior usually longer than wide, $0.4-0.6 \times$

Publ. Seto Mar. Biol. Lab., VII (3), 1959. (Article 20) 
$0.26-0.5 \mathrm{~mm}$, posterior wider than long, $0.25-0.44 \times 0.33-0.6 \mathrm{~mm}$. Seminal vesicle subglobular, situated between Säfftigen's pouch and bursa, $0.26-0.42 \times 0.2-0.4 \mathrm{~mm}$. Cement glands 8 , claviform, with their swollen ends close together between posterior testis and Säfftigen's pouch. Säfftigen's pouch $0.3-0.5 \mathrm{~mm}$ in diameter. Paired diverticles of muscular bursal cap about $0.17 \mathrm{~mm}$ in diameter; bursal rays short, numerous, folded. Genital pore terminal.

Female. Proboscis subcylindrical, $0.45-0.6 \times 0.3-0.4 \mathrm{~mm}$, with $23-30$ longitudinal rows of 8-10 hooks each; largest subapical hooks $65-78 \mu$ long, smallest basal hooks 39-62 $\mu$ long. Neck very short. Proboscis sheath cylindrical or subcylindrical, 1.1$1.7 \times 0.2-0.32 \mathrm{~mm}$. Lemnisci $1.3-2.0 \mathrm{~mm}$ long in extended condition. Uterine bell more or less elongated goblet-shaped, $0.14 \times 0.1 \mathrm{~mm}$ in the type $16.5 \mathrm{~mm}$ long. Uterus divided into two portions of different structure, the anterior portion $(0.18 \times 0.07 \mathrm{~mm}$ in the type) appears as if it were telescoped into the posterior portion, which is cylindrical, $0.18 \times 0.08 \mathrm{~mm}$ in the type, and contains medullary tissue between the inner lining and the outer muscular capsule. Vaginal funnel enclosed in uterus, its posterior portion lying outside the uterus, surrounded by a sphincter, which in turn is enclosed in the outer sphincter of spiral bands; vaginal bulb opening terminally, $0.11 \mathrm{~mm}$ in diameter. As measured in life the elongate elliptical outer egg shell is $77-81 \mu$ long by $13 \mu$ wide, the middle shell with polar prolongations $60 \mu$ long and the inner shell $54-56 \mu$ long.

This genus is characterized by the anterior position of the ganglion and the number of the cement glands, though agreeing in other characters with Acantho. cephalus.

\section{Metacanthocephalus n. g.}

Generic diagnosis.-Echinorhynchinae of medium size. Trunk subcylindrical, with numerous, small, partly branched, hypodermal nuclei. Lacunar system reticular. Proboscis subcylindrical, with numerous longitudinal rows of several hooks each. Neck short. Proboscis sheath cylindrical to claviform, long, double-walled, with ganglion at its anterior end. Lemnisci elongate, usually longer than proboscis sheath. Testes rounded, directly tandem, in midregion of trunk or a little behind it. Cement glands 8 , compact, close together between posterior testis and Säff tigen's pouch. Säfftigen's pouch and seminal vesicle well developed. Muscular cap of bursa with anterior diverticula, provided posteriorly with numerous short folded rays. Uterine bell goblet-shaped; vagina with an outer and an inner sphincter. Egg elongate elliptical, with polar prolongations of middle shell. Parasitic in marine teleosts.

Genotype: M. pleuronichthydis n. sp.

\section{Metacanthocephaloides zebrini n. g., n. sp.}

(Pl. XXVI, Figs. 8-10)

Habitat: Small intestine of Zebrias zebrinus, Inegocia meerdervoorti, Pleuronichthys cornutus and Paralichthys olivaceus. 
Material : 15 males and 30 females, more or less contracted, from first host, 6 males and 20 females from second host, one male and two females from third host, and three females from fourth host; all mature but not fully gravid.

Locality and date: Inland Sea of Japan; April 29, 1957.

Male. Trunk cylindrical, $2.0-2.3 \mathrm{~mm}$ in length, with maximum breadth of $0.5 \mathrm{~mm}$; hypodermic nuclei small, numerous, partly branched. Lacunar system reticular. Neck short. Proboscis ovoid to subcylindrical, more or less swollen near middle, 0.3-.5x 0.12-0.28 mm ; proboscis hooks in 23-25 longitudinal ${ }^{1)}$ rows of 6-9 hooks each; largest subapical hooks with short backwardly directed root, up to $56-78 \mu$ long; smallest basal hooks $39-52 \mu$ long. Proboscis sheath subcylindrical, double-walled, $0.4-0.75 \mathrm{~mm}$ $(0.9 \mathrm{~mm}$ when fully extended) long by $0.1-0.2 \mathrm{~mm}$ broad, reaching to anterior testis; elliptical ganglion situated at or near anterior end of proboscis sheath. Lemnisci claviform or cylindrical, usually a little shorter than proboscis sheath. Testes subglobular to ovoid, directly tandem in anterior half of trunk, $0.2-0.5 \times 0.24-0.52 \mathrm{~mm}$; sometimes occupying whole breadth of trunk cavity. Seminal vesicle well developed, $0.15-0.28 \times 0.1-0.23 \mathrm{~mm}$, situated obliquely immediately anterior to muscular cap of bursa. Cement glands 6 , compact, irregular in shape, massed together immediately behind posterior testis. Bursal cap without paired anterior diverticula, provided at its posterior border with a number of short lobular projections. Non-muscular portion of bursa (bursa proper) provided inside with numerous small tubercles, constricted posteriorly by sphincter-like muscle bundles, and opening terminally by wide aperture.

Female. Trunk $3.0-5.5 \times 0.5-0.7 \mathrm{~mm}$, with numerous, small, partly branched, hypodermal nuclei. A short neck present. Proboscis subcylindrical, more or less swollen toward middle; $0.4-0.6 \times 0.24-0.26 \mathrm{~mm}$; proboscis hooks in $23-28$ longitudinal rows of 7-10 hooks each. Proboscis sheath elongate, $0.6-0.9 \mathrm{~mm}$ (1.1 mm when fully extended) long by $0.13-0.23 \mathrm{~mm}$ broad, with ganglion at its anterior end. Lemnisci a little shorter than proboscis sheath. Uterine bell with comparatively narrow aperture, dilated posteriorly (about $40 \mu$ wide), $0.44 \mathrm{~mm}$ in length combined with uterine duct. Uterus proper $0.2 \times 0.06 \mathrm{~mm}$, enclosing vaginal funnel posteriorly. Vaginal bulb $0.12 \mathrm{~mm}$ in diameter, opening into terminal sinus, which is about $0.3 \mathrm{~mm}$ deep in the type. On each side of the vagina is a very conspicuous two-lobed giant cell sui generis measuring $0.15-0.18 \times 0.11-0.13 \mathrm{~mm}$ and containing very finely granular protoplasm and a large round nucleus about $25 \mu$ in diameter; it is enclosed in a thick $(5-10 \mu)$ capsuIe of homogeneous structure and situated a little obliquely with its base directly on the anterolateral part of the vaginal bulb. Immature eggs scattered diffusely in cavity of trunk, no mature eggs observed.

The present genus resembles Metacanthocephalus very closely, but differs from it in the number of cement glands and in the presence of a peculiar giant cell on

1) 19 longitudinal rows in the male from Pleuronichthys cornutus. 
each side of the vagina. The latter structure has never been observed in any acanthocephalans so far as I am aware.

\section{Metacanthocephaloides $\mathrm{n} . \mathrm{g}$.}

Generic diagnosis.-Echinorhynchinae of submedium size. Trunk cylindrical, with numerous, small, partly branched, hypodermal nuclei. Lacunar system reticular. Neck short. Proboscis ovoid to subcylindrical, with numerous (23-28) longitudinal rows of several hooks each; hooks becoming gradually larger from apex toward middle of proboscis and thence gradually smaller, attaining minimum length at base. Proboscis receptacle long, double-walled, with ganglion at its anterior end. Lemnisci digitiform or claviform, not very long. Testes rounded, directly tandem, pre-equatorial. Cement glands 6, compact, close together behind posterior testis. Säfftigen's pouch and seminal vesicle well developed. Muscular cap of bursa without anterior diverticula, provided posteriorly with a circle of short lobular appendages. Uterine bell not gaping anteriorly. On each side of the vagina is a very conspicuous, mononuclear, giant cell of unknown nature. Eggs? Parasites of marine teleosts.

Genotype: M. zebrini n. sp.

\section{RHADINORHYNCHIDAE TRAVASSOS, 1923}

\section{Metarhadinorhynchus lateolabracis n. g., n. sp.}

(Pl. XXVI, Figs. 4-7)

Habitat: Small intestine of Lateolabrax japonicus (Temm, et Schleg.)

Material: One mature male and two young females.

Locality and date: Inland Sea; September 9, 1957.

Male. Proboscis claviform, about $0.43 \mathrm{~mm}$ long by $0.17 \mathrm{~mm}$ broad near apex, with 23 longitudinal rows of about 20 hooks each ${ }^{1)}$; hooks increasing in size from the apex toward the broadest subapical region, where they are stout and measure 54-56 $\mu$ long, and whence they gradually decrease in size toward the base of the proboscis, attaining a minimum length of about $25 \mu$. Neck short trapezoidal. Proboscis sheath approximately fusiform, $0.85 \times 0.24 \mathrm{~mm}$, double-walled; ganglion nearly equatorial. Retinacula leaving proboscis sheath behind its middle. Lemnisci filiform, winding, reaching far beyond base of proboscis sheath. Trunk long, slender, cylindrical, $13.5 \mathrm{~mm}$ by $0.57 \mathrm{~mm}$ in moderately contracted state; somewhat tapering anterior part covered all round for a distance of $0.3 \mathrm{~mm}$ with spines which are $23-40 \mu$ long, imbedded in the cuticular folds and arranged nearly in quincunx; no separate group of spines elsewhere. Hypodermal nuclei small, numerous; lacunar system reticular.

Testes elongated elliptical, tandem near anterior end of trunk, partly overlapping each other, anterior measuring $0.95 \times 0.28 \mathrm{~mm}$ and posterior $0.76 \times 0.25 \mathrm{~mm}$. Vesicula seminalis elongate fusiform, $0.13 \mathrm{~mm}$ wide, posteroventral to Säfftigen's pouch. Cement

1) The exact number of the hooks in each row is unable to make out owing to the proboscis being invaginated at the apex. 
glands 8 in number, very long and filiform, massed together on each side into a bundle and then forming a smollen duct $0.2 \mathrm{~mm}$ wide at attenuated posterior portion of Säfftigen's pouch. Säfftigen's pouch elongate, nearly $1 \mathrm{~mm}$ long, forming a bulbous dilatation $0.37 \mathrm{~mm}$ in diameter at about middle, whence it tapers abruptly both backwards and forwards. Muscular cap of bursa with paired anterior diverticles as usual ; posterior bursal rays not well differentiated. Between the bursa and the terminal genital pore is a large sphincter about $0.2 \mathrm{~mm}$ in diameter.

Female. Proboscis claviform, about $0.45-0.5 \mathrm{~mm}$ long, $0.24-0.27 \mathrm{~mm}$ wide at subapical swelling, with 23-25 longitudinal rows of about 20 hooks each; largest subapical hooks $52-65 \mu$ long, smallest basal hooks $31 \mu$ long. Neck $0.15-0.16 \mathrm{~mm}$ long. Proboscis sheath elongate elliptical, $0.75-0.9 \times 0.29 \mathrm{~mm}$, with its double-layered wall perforated by retinacula behind its middle; ganglion pre-equatorial. Lemnisci tubular, long, crumpled. Trunk $13.7-22 \mathrm{~mm}$ long by $0.6-0.9 \mathrm{~mm}$ broad in contracted state; its anterior end attenuated and covered in quincunx with alate spines $26-47 \mu$ long as in male for a distance of $0.25-0.3 \mathrm{~mm}$. Germ cells forming masses of varying dimensions, some of them scattered, others packed together in posterior part of trunk. Uterus tubular very long. The vagina distinctly divided into two bulbous portions; in the type the anterior bulb corresponding to the vaginal funnel is $52 \mu$ long by $47 \mu$ broad, and the elliptical posterior bulb $65 \mu$ long by $36 \mu$ broad. There are two vaginal sphincters; the anterior, $59 \mu$ in diameter in the type, surrounds the constricted part of the vagina, and the posterior, $55 \mu$ in diameter, surrounds the posterior end of the vagina and rests on the terminal vaginal bulb which is $65 \mu$ in diameter. Vulva subterminal, about $0.4 \mathrm{~mm}$ from the blunt tail end. Eggs not yet developed.

This genus, apparently belonging to the family Rhadinorhynchidae, is related to Rhadinorhynchus LüHE, 1911, but differs from it in possessing 8 cement glands.

\section{Metarhadinorhynchus n. g.}

Generic diagnosis.-Rhadinorhynchidae. Trunk cylindrical or subcylindrical, with numerous, small, hypodermal nuclei, covered anteriorly with spines which are imbedded in cuticular folds and arranged in quincunx, forming a single continuous group. Proboscis somewhat claviform, with numerous longitudinal rows of hooks which increase in size from the apex of the proboscis down to the broadest subapical region and then decrease toward the base; basal spines the smallest and not projecting very prominently. Neck short. Proboscis sheath fusiform to elongate elliptical, double-walled, with ganglion near its middle. Lemnisci slender, long. Testes tandem, contiguous, in anterior third of trunk. Seminal vesicle elongate. Cement glands 8, tubular, very long, forming paired elongate reservoirs posteriorly, one on each side of seminal vesicle and attenuated posterior portion of Säfftigen's pouch. Uterus tubular, very long; vagina divided into two bulbous portions, anterior bulb representing the vaginal funnel; two (an anterior and a posterior) vaginal sphincters and terminal vaginal bulb present; vulva subterminal. Eggs ? Parasitic in marine teleosts.

Genotype: M. lateolabracis n. sp. 


\section{Allorhadinorhynchus segmentatum n. g., n. sp.}

(P1. XXVI, Figs. 11-13)

Habitat: Small intestine of Hyporhamphus sayori (TEMM. et Schleg.)

Material: Two mature males and two gravid females.

Locality and date: Inland Sea; September 13, 1957.

Male. Trunk subcylindrical, $1.8-2.1 \mathrm{~mm}$ in length, with maximum width of $0.24-$ $0.3 \mathrm{~mm}$ at level of Säfftigen's pouch or muscular bursal cap, pseudosegmented almost throughout at intervals of $30-60 \mu$ (over 40 annuli in the type $2.1 \mathrm{~mm}$ long), covered anteriorly for a short distance $(0.45 \mathrm{~mm}$ in the type) with slender spines which are 13-18 $\mu$ long, imbeded in cuticular folds and arranged in quincunx; posterior extremity containing refractive tissue similar to that of Säfftigen's pouch, projecting in form of a blnnt-conical or rounded knob $70-100 \mu$ in diameter. Lateral longitudinal lacunar stem more or less reticular, connecting circular vessel of each annulus. Hypodermal nuclei small, oval to elliptical, confined to lacunar vessels. Neck very short. Proboscis subcylindrical to claviform, $0.3-0.4 \times 0.11 \mathrm{~mm}$, broadest subapically, with 12 longitudinal rows of slender hooks abruptly diminishing basally; 10-11 hooks in each row; largest apical hooks $65-72 \mu$ long, smallest basal hooks $13 \mu$ long. Proboscis sheath cylindrical, $0.7-0.73 \times 0.08-0.09 \mathrm{~mm}$, double-walled, with elongate ganglion at about its middle. Lemnisci sausage-shaped, $0.35-0.4 \times 0.07-0.08 \mathrm{~mm}$, containing numerous small nuclei.

Testes elliptical, tandem, contiguous, largely pre-equatorial ; anterior testis 0.34 $0.38 \times 0.11-0.12 \mathrm{~mm}$, with its greater part overlapping posterior portion of proboscis sheath, posterior testis $0.26-0.3 \times 0.11-0.15 \mathrm{~mm}$, with its posterior end overlapping anterior end of cement glands. Seminal vesicle rounded, about $60 \mu$ in diameter, situated just in front of bursal cap. Cement glands cylindrical, extending closely side by side between posterior testis and bursal cap. Säfftigen's pouch claviform, $0.34-0.4 \times 0.1-0.12 \mathrm{~mm}$. Muscular cap of bursa with symmetrical, triangular, anterior recesses, and 8 , digitiform, posterior rays. Genital pore ventro-subterminal, at base of above mentioned terminal knob.

Female. Trunk 2.6-3.05 $\mathrm{mm}$ long, gradually tapering toward ventrally curved tail end, which terminates in a small blunt-conical or rounded knob, $0.4-0.52 \mathrm{~mm}$ in maximum breadth near anterior end, pseudosegmented throughout as in male at intervals of $30-100 \mu$ (43 annuli in the type $3.05 \mathrm{~mm}$ long), covered anteriorly for a distance of $0.5-0.8 \mathrm{~mm}$ with slender spines which are $13-20 \mu$ long and imbedded in cuticular folds. In the type the dorsal spines extend down to the 11th annulus, while the ventral spines reach to the 13 th annulus. Neck very short. Proboscis claviform, $0.4-0.5 \mathrm{~mm} \times 0.16-0.17 \mathrm{~mm}$, with 12 longitudinal rows of $9-10$ hooks each; largest apical hooks $65-78 \mu$ long, smallest basal hooks $13-18 \mu$ long. Proboscis sheath cylindrical, double-walled, $0.8 \times 0.1-0.14 \mathrm{~mm}$. Lemnisci $0.5-0.55 \times 0.1-0.12 \mathrm{~mm}$.

Uterus narrow (15 $\mu$ wide) and very long; its posterior portion enclosing the

$$
-30-
$$


vaginal funnel is very long $(0.25 \mathrm{~mm})$ and $31 \mu$ in maximum width in the type. There is only one sphincter $34 \mu$ in diameter; vaginal bulb pyriform, $65 \mu$ long by $44 \mu$ wide. Vulva ventrosubterminal, at base of terminal knob. Eggs elongated elliptical, threeshelled; outer shell about $56 \mu$ long by $13 \mu$ broad as mounted in balsam; middle shell with very prominent polar prolongations.

This species is characterized by the spination of the trunk like Rhadinorhynchus species, and moreover by a comparatively regular pseudosegmentation of the trunk wall with well developed annular lacunar system corresponding to the pseudosegmentation, to which the specific name refers. That the bursal rays are digitiform and comparatively few in number, and that the vaginal funnel is unusually long and followed by a single sphincter, together with the subterminal genital pores in both sexes are important distinguishing characters. There is no doubt that this species represents a new genus of the family Rhadinorhynchidae, for which the name Allorhadinorhynchus is suggested.

\section{Allorhadinorhynchus n. g.}

Generic diagnosis.-Rhadinorhynchidae. Trunk elongate, with irregular posterior swelling in male, but gradually tapered posteriorly in female, with comparatively regular pseudosegmenta. tion throughout its length and well developed circular lacunar vessel for each annulus; hypo. dermal nuclei confined to lacunar vessels; anterior part of trunk covered in quincunx with slender curved spines which are imbedded in cuticulrr folds and extend on the ventral side a little further backward than on the dorsal side in the female. Proboscis claviform, with a number of longitudinal rows of slender hooks. Neck very short. Proboscis sheath cylindrical, long, double-walled, with ganglion at about its middle. Lemnisci comparatively short, containing numerous small nuclei. Testes tandem, contiguous, largely pre-equatorial; seminal vesicle rounded. Cement glands 2, cylindrical. Säfftigen's pouch elongate. Bursal rays digitiform, comparatively few in number; male genital pore subterminal, at base of terminal knob, whose pulp is similar to that of Säfftigen's pouch. Female tail curved ventrad, terminating in a small knob. Uterus long and narrow, vaginal funnel unusually long, followed by single sphincter, vaginal bulb well developed. Vulva subterminal, at base of terminal knob. Eggs three-shelled, middle shell with prominent polar prolongations.

Genotype: A. segmentatum n. sp.

\section{Acknowledgments}

I wish to express my gratitude to Mr. S. ÔBA and Mr. T. YAmASU of the Marine Laboratory of Okayama University at Shibukawa, Tamano City, Okayama Prefecture, for their help extended to me during my stay at the Laboratory for collecting the fish parasites described here.

\section{LITERATURE}

CHANDleR, A. C. 1934. A revision of the genus Rhadinorhynchus (Acanthocephala) with desciptions of new genera and species. Parasit., 26 (3), 352-358. 
FukuI, T. 1929. On some Acanthocephala found in Japan. Annot. Zool. Jap. 12, 255-270.

Fukur, T. and MorisitA, T. 1937. Studies on Japanese Acanthocephala (Japanese text). Zikken Igaku Zasshi 21, 36-41.

1938. Note on the acathocephalan fauna of Japan. Annot. Zool. Jap. 17 (3-4), 567-576.

HARADA, I. 1938. Acanthocephalen aus Formosa. I. Ibid. 17 (3-4), 419-427.

LüHE, M. 1911. Acathocephalen. BRAuER's Süsswasserfauna Deutschlands. Heft 16.

MEYER, A. 1932-33. Acanthocephala. BronN's Klass. u. Ordn. d. Tierreichs B. 4, Abt. 2, Buch 2, Lief. 1-2, $582 \mathrm{pp.}$

Travassos, L. 1921. Contribuição para o conhecimento dos acanthocephalos da subfamilia Centrorhynchinae. Folha Medica 2 (6), 42-43.

1924. Contribuições para o conhecimento da fauna helmintolojica brasileira

XVII. Revisão dos acanthocephalos brasileiros. I. Fam. Giganthorhynchidae Hamann, 1892Supplemento. Mem. Inst. Osw. Cruz, 17, 365-375.

1926. Contribuições para o conhecimento da fauna helminthogica brasileira.

XX. Ravisão dos acanthocephalos brasileiros. Parte II. Familia Echinorhynchinae Travassos, 1919. Ibid. 19 (1), 31-125.

VAN Cleave, H. J. 1918. Acanthocephala of the subfamily Rhadinorhynchinae from American fish. J. Parasit. 5, 17-24.

1928. Acanthocephala from China, I. New species and new genera from China fishes. Parasit. 20, 1-9.

1929. Two new genera and species of Acanthocephala from fishes of India.

Rec. Ind. Mus 30 (2), 147-149.

WitenBeRG, G. G. 1932. Akanthocephalen-Studien. II. Über das System der Akanthocephalen. Boll. Zool. Napoli 3 (5), 253-266.

Yamaguti, S. 1935. Studies on the helminth fauna of Japan. Pt. 8. Acanthocephala, I. Jap. J. Zool. 6 (2), 247-278.

1939. Idem. Pt. 29. Acanthocephala, II. Ibid. 13 (3), 317-351.

\section{EXPLANATION OF PLATE XXVI}

Figs. 1-3. Metacanthocephalus pleuronichthydis n. g., n. sp.

1, Male. 2, Female terminalia. 3, Proboscis hooks.

Figs. 4-7. Metarhadinorhynchus lateolabracis n. g., n. sp.

4, Anterior extremity of male. 5, Posterior extremity of male.

6, Female terminalia. 7, Posterior extremity of female.

Figs. 8-10. Metacanthocephaloides zebrini n. g., n. sp.

8, Male. 9, Proboscis hooks. 10, Posterior extremity of female.

Figs. 11-13. Allorhadinorhynchus segmentatum n. g., n. sp.

11, Male. 12, Proboscis hooks. 13, Female terminalia. 
Publ. Seto Mar. Biol., Lab., VII, 3 (1959) PLATE XXVI

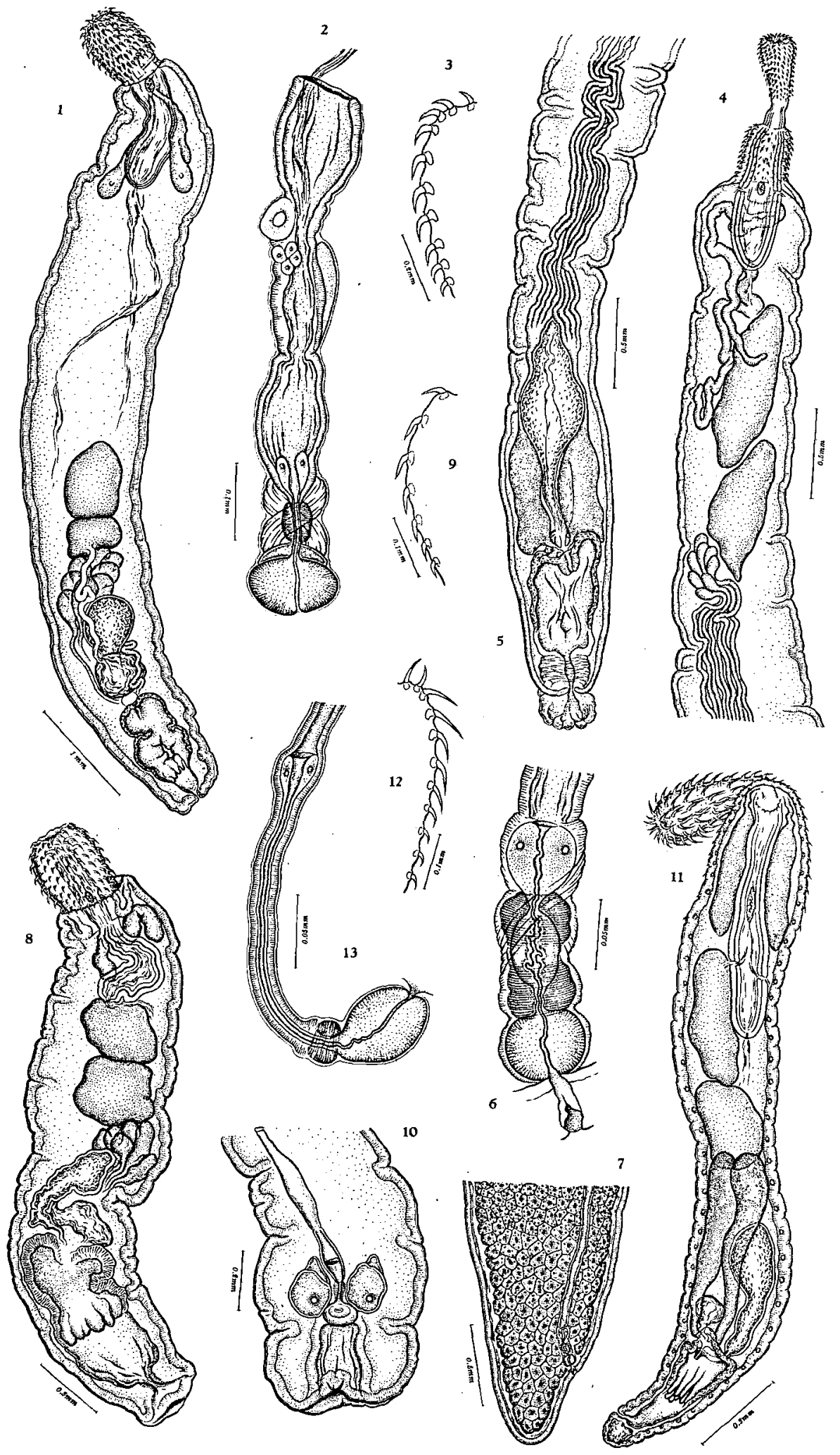

S. Yamaguti: Studies on the Helminth Fauna of Japan, 55. 